\title{
Analysis of Caesarean Section Using Robson's 10-Group Classification at a Tertiary Level Hospital in Nepal
}

\author{
Rosy Vaidya Malla, Chanda Hamal, Bibhusan Neupane and Ratna Khatri
}

Department of Obstetrics and Gynaecology, Nepalese Army Institute of Health Sciences, Shree Birendra Hospital, Chhauni, Kathmandu, Nepal

\begin{abstract}
Introduction: Obstetric Services commenced at the teaching institute where this study was conducted from August 2012. Hence, a review of the data of C-section in this hospital is needed for standardisation of the obstetric services in terms of the rate of $\mathrm{C}$-section, its various clinical indications and maternal and fetal outcomes.

Methods: This is a retrospective study carried out over a period of five years from August 13, 2012 to August 11, 2017. All hospital deliveries conducted during the study period were included in this study and the patients' details were obtained from hospital records. All data obtained was recorded in master charts and analysed using SPSS version 23. The caesarean rate, its indications were calculated and categorised into groups according to Robson's 10-group classification.

Results: A total number of 4892 deliveries were conducted over this five year study period. C-section was performed in 1104 patients, giving a $\mathrm{C}$-section rate of $22.57 \%$. The most common indications were previous C-section (25.4\%), fetal distress (14.3\%) and breech presentation (10.3\%). Robson's Group 1 was the highest contributors to the overall CS rate, contributing $28 \%$ of all C-sections, followed by Group $5(26.8 \%)$ and Group $3(15.5 \%)$.

Conclusions: Nulliparous and multiparous women in term pregnancy in labor and women with previous C-section contribute to more than $70 \%$ of overall C-sections at our centre. Hence, close monitoring of these groups of patients, increasing the use of instrumental delivery and practice of vaginal birth after $\mathrm{C}$ section can significantly reduce the $\mathrm{C}$-section rate in our centre.
\end{abstract}

Keywords: caesarean rate; caesarean section; Robson's 10 group Classification

Correspondence: Rosy Vaidya Malla, Department of Obstetrics and Gynaecology, Nepalese Army Institute of Health Sciences, Shree Birendra Hospital, Chhauni, Kathmandu, Nepal. Email: rosymalla@hotmail.com

DOI: http://dx.doi.org/10.3126/mjsbh.v17i2.20290

Submitted on: $2018-06-16$

Accepted on: 2018-06-27 


\section{INTRODUCTION}

Introduction of Caesarean section surgery into the field of obstetrics has been associated with an improvement in maternal and overall perinatal health outcomes. However, in many developed countries, there has been concern regarding the higher rates of caesarean section. ${ }^{1}$ Caesarean section also has its own risks for maternal as well as infant morbidity and for subsequent pregnancies. ${ }^{2,3}$ These risks will outweigh the potential benefits associated with lowering the threshold at which the procedure becomes indicated at some point. ${ }^{4}$

Various guidelines, especially by the World Health Organisation and the United States Healthy People 2000 initiative suggest the optimal caesarean section rate (CSR) to be $15 \% .5,6$ However, regional variation is prevalent in CSR. According to the latest data from 150 countries, Latin America and the Caribbean region have the highest CSR (40.5\%), followed by Northern America (32.3\%), Oceania (31.1\%), Europe (25\%), Asia (19.2\%) and Africa (7.3\%). ${ }^{1}$ Recently, WHO has stated that no empirical evidence exists for an ideal CSR, but "what matters the most is that all women who need caesarean sections actually receive them."7

In an effort to reduce the rising CSR in developed countries, the need of a standardised classification system for C-section that would allow meaningful and relevant comparisons of CSR across different facilities, cities or regions was felt. ${ }^{8}$ The Robson's 10 group classification, proposed by Dr Michael Robson in 2001, stratifies women according to their obstetric characteristics, thereby allowing a comparison of CSR with fewer confounding factors. ${ }^{9} \mathrm{WHO}$ conducted two systemic reviews in 2011 and 2014 and concluded Robson classification to be the most appropriate system to fulfil international and local needs. 8,10 WHO further stated that this classification system would help healthcare facilities to optimise the use of caesarean section by identifying, analysing and focusing interventions on specific groups of particular relevance for each health care facility. Subsequent assessment of the effectiveness of strategies or interventions targeted at optimising the use of caesarean section, the quality of care, clinical management practices and outcomes by group can be performed using this classification system. ${ }^{7}$

Our institute was established in $1925 \mathrm{AD}$ by the then government of Nepal with the intention of providing medical services to the army personnel injured during the First World War. Later in 1989, it was relocated at Chhauni with radical improvements and modernisation of medical services. Though Gynaecological services and ANC were being provided since early days, fullfledged Obstetric services commenced only recently from Aug 2012. Hence, a review of the data of Caesarean section being provided in this hospital was needed for assessment and standardisation of the obstetric services.

\section{METHODS}

This is a retrospective study carried out over a period of five years from Aug 13, 2012 to Aug 11, 2017. All hospital deliveries conducted during the study period were included in the study. Exclusion criteria remained all IUFD that occurred during the study period. From the OT record book kept at the Maternity OT of the hospital, operative details of patients who had undergone C-section were obtained. From the patients' hospital inpatient number, further details of the patient were obtained from hospital records. Patients' demographic dataage, parity, gravidity, pregnancy related information- gestational age, foetal presentation, number of foetuses, onset of labor, delivery detailsoperative or vaginal delivery, indications of CS, type of C-section, foetal details - APGAR scores, NICU admission were all recorded. Foetal 
presentation was classified as cephalic, breech or transverse/oblique. Gestational age was categorised as a term $\geq 37$ weeks or preterm $<37$ weeks. Gestational age was assessed using early USG or LMP.

Based on patients' data, women were assigned to one of 10 groups as per Robson's 10-group classification system (Table 1). This classification system categories women into ten mutually exclusive groups, considering the following criteria: parity, previous obstetric record of the woman, the course of labor including pre-labor duration and gestational age.

All data obtained were recorded in master charts and analysed using SPSS version 23. Results were then presented as tables and graphs including frequencies, percentages, means and SD. Ethical

Table 1. Robson's 10 Group Classification

\begin{tabular}{|c|c|}
\hline Group & Description \\
\hline 1 & $\begin{array}{l}\text { Nulliparous, single cephalic, } \geq 37 \\
\text { weeks, in spontaneous labor }\end{array}$ \\
\hline 2 & $\begin{array}{l}\text { Nulliparous, single cephalic, } \geq 37 \\
\text { weeks, induced or CS before labor }\end{array}$ \\
\hline 3 & $\begin{array}{l}\text { Multiparous (excluding prev. CS), } \\
\text { single cephalic, } \geq 37 \text { weeks, in } \\
\text { spontaneous labor }\end{array}$ \\
\hline 4 & $\begin{array}{l}\text { Multiparous (excluding prev. CS), } \\
\text { single cephalic, } \geq 37 \text { weeks, induced or } \\
\text { CS before labor }\end{array}$ \\
\hline 5 & $\begin{array}{l}\text { Previous CS, single cephalic, } \geq 37 \\
\text { weeks }\end{array}$ \\
\hline 6 & All nulliparous breeches \\
\hline 7 & $\begin{array}{l}\text { All multiparous breeches (including } \\
\text { previous CS) }\end{array}$ \\
\hline 8 & $\begin{array}{l}\text { All multiple pregnancies (including } \\
\text { previous CS) }\end{array}$ \\
\hline 9 & $\begin{array}{l}\text { All abnormal lies (including previous } \\
\text { CS) }\end{array}$ \\
\hline 10 & $\begin{array}{l}\text { All single cephalic, } \leq 36 \text { weeks } \\
\text { (including previous CS) }\end{array}$ \\
\hline
\end{tabular}

approval for the study was obtained from the Institutional Review Committee.

\section{RESULTS}

During the study period of 5 years, total number of 4892 deliveries were conducted of which, 1104 were by caesarean section giving the overall CSR of $22.57 \%$. Age of the patients varied from $16 \mathrm{yrs}$ to $47 \mathrm{yrs}$ with the mean of 26.9 yrs. Sociodemographic characteristics and obstetric conditions are summarised in table 2.

In our study, nulliparous, single cephalic women at term in spontaneous labor (Robson's Group 1) were the highest contributors to the overall CSR, contributing $28 \%$ of all caesarean sections (Fig. 1). The second highest contributors were women with a single cephalic presentation at term and previous CS (Group 5) contributing 26.8\% to the overall CS. The third highest contributor were multiparous single cephalic women at term and in spontaneous labor (Group 3) with $15.5 \%$. Hence, these three groups (1, 5 and 3$)$ contribute to more than $70 \%$ of all Caesarean sections carried out during the study

Table 2. Socio-demographic characteristics and obstetric conditions

\begin{tabular}{|r|r|r|r|}
\hline SN & Maternal Characteristics & Number & $\%$ \\
\hline 1 & Parity & 485 & $44 \%$ \\
\hline & Primi & 619 & $56 \%$ \\
\hline 2 & Multi & & \\
\hline & Maternal Age (Yrs) & 411 & $37 \%$ \\
\hline & $16-25$ & 658 & $60 \%$ \\
\hline & $26-35$ & 34 & $3 \%$ \\
\hline 3 & Type of CS & 1 & \\
\hline & Elective & 422 & $38 \%$ \\
\hline & Emergency & 682 & $62 \%$ \\
\hline
\end{tabular}




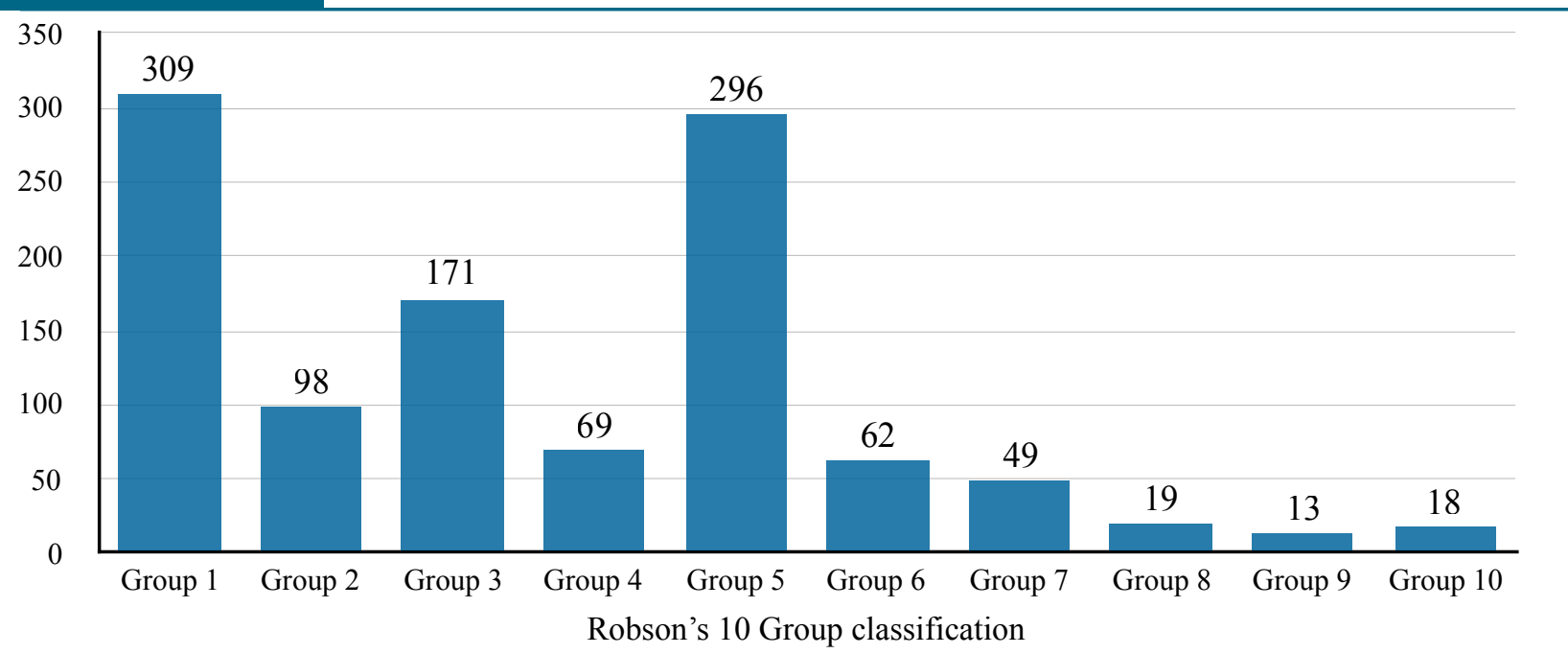

Fig 1. Distribution of Caesarean Sections at SBH according to Robson's 10 Group

period. Breech presentation, twin pregnancies and abnormal lie contributed $13 \%$ of all CS while single cephalic in preterm contributed to $1.6 \%$ of CS.

Table 3. Fetal characteristics

\begin{tabular}{|c|c|c|c|}
\hline SN & $\begin{array}{l}\text { Fetal } \\
\text { Characteristics }\end{array}$ & Number & \\
\hline \multirow[t]{3}{*}{1} & Fetal outcome & & \\
\hline & Alive & 1095 & $99 \%$ \\
\hline & Stillbirth & 9 & $1 \%$ \\
\hline \multirow[t]{3}{*}{2} & NICU admission & & \\
\hline & Elective CS & 13 & $3 \%$ \\
\hline & Emergency CS & 88 & $13 \%$ \\
\hline \multirow[t]{3}{*}{3} & $\begin{array}{l}\text { APGAR score } \leq 5 \\
\text { at } 5 \text { mins }\end{array}$ & & \\
\hline & Elective CS & 5 & $1 \%$ \\
\hline & Emergency CS & 20 & $3 \%$ \\
\hline \multirow[t]{5}{*}{4} & $\begin{array}{l}\text { Perinatal } \\
\text { mortality }\end{array}$ & & \\
\hline & Total deliveries & $28 / 4892$ & $\begin{array}{r}6 \text { per } 1000 \\
\text { pregnancies }\end{array}$ \\
\hline & C Section & $10 / 1104$ & $\begin{array}{r}9 \text { per } 1000 \\
\text { pregnancies }\end{array}$ \\
\hline & Elective CS & $2 / 422$ & $\begin{array}{r}5 \text { per } 1000 \\
\text { pregnancies }\end{array}$ \\
\hline & Emergency CS & $8 / 682$ & $\begin{array}{l}12 \text { per } 1000 \\
\text { pregnancies }\end{array}$ \\
\hline
\end{tabular}

As depicted in figure 2, previous CS remained the most common indication for performing caesarean section, followed by foetal distress and abnormal presentations. Perinatal morbidity and mortality was understandably higher in the emergency CS compared to elective CS as shown in table 3.

\section{DISCUSSION}

Following a meeting of panel of reproductive health in 1985 in Fortaleza, Brazil, WHO stated that there is no justification for any region to have a CSR higher than $10 \%$ to $15 \% .^{5}$ More recently, based on its systemic review in 2014, WHO has stated that every effort should be made to provide

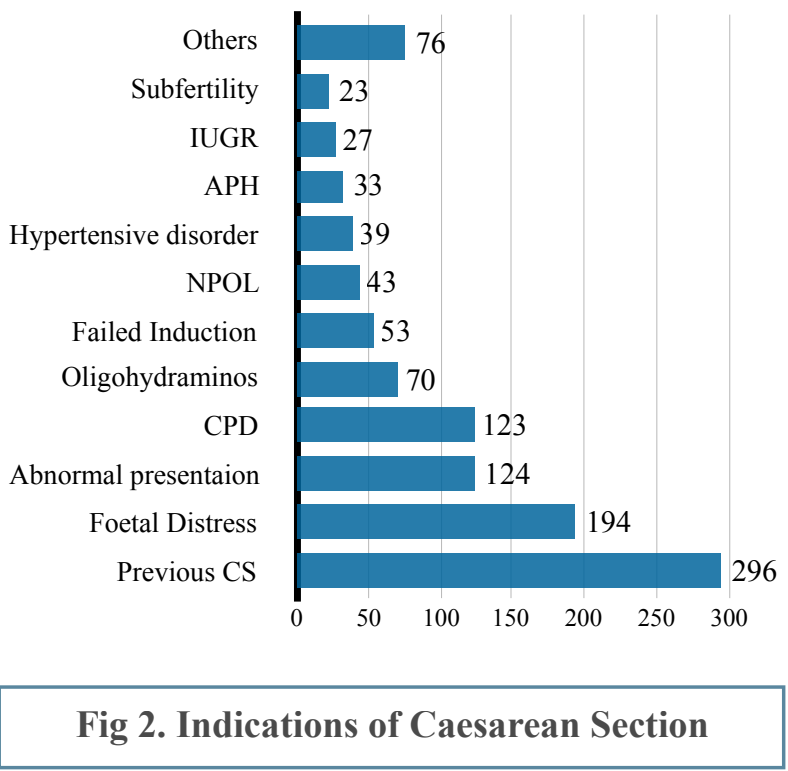


caesarean sections to women in need, rather than striving to achieve a specific rate. ${ }^{7}$

The Overall CSR of $22.57 \%$ reported in our study, compare favourably with other hospitals in the country. Paropakar Maternity and Women's Hospital, the largest Tertiary referral centre of the country has reported an annual CSR $24 \%$ to $27 \%$ in the same time period. ${ }^{11}$ Amatya et al. reported a CSR of $16.6 \%$ to $25.4 \%$ over 2005 to 2010 at Tribhuvan University Teaching Hospital. ${ }^{12}$ Similar CSR published from Eastern Nepal from a tertiary referral centre remained $28.6 \%$ (2006) to $33.7 \%$ (2007). ${ }^{13}$ Western regional hospital in Pokhara, Nepal reported CSR of $24.25 \%$ during 2013 to 2015.14

Internationally, the highest CSR in the world is reported from Southern America subregion with 42.9\%. Similarly, Latin America and the Caribbean countries have $40.5 \%$ of CSR whereas Africa has the lowest average CSR with $7.3 \%$, with minimum $3.5 \%$ in sub-Saharan Africa and maximum 27.8\% in Northern Africa. ${ }^{15}$

In our study, groups 1, 5 and 3 were the major contributor to the overall CSR accounting for more than $70 \%$ of all CS. Similar findings have been reported in studies from developing countries. A recent study from Ethiopia report a CSR of $25.7 \%$ with groups 3, 5 and 1 being the major contributors to the overall CSR. ${ }^{16}$ Another study from South Africa reported groups 1, 5 and 3 to be the major contributors to the CSR. ${ }^{17}$ Similarly, Litorp et al., reported groups 1,3 and 5 to be the leading contributors in Tanzania. ${ }^{18}$ A similar study in our subcontinent from India reported a 10-year overall CSR of $25.17 \%$ with groups 1,5 and 3 being the largest contributors. ${ }^{19}$

The performance of CS among low-risk groups (groups 1, 2, 3 and 4) for non-absolute medical indications (foetal compromise, failure to progress) should be analysed in detail. Close monitoring of patients in these groups with adequate recording of foetal heart rate on partograph is required. Increasing the use of instrumental delivery by adequate training of staff is warranted to decrease primary caesarean among low-risk groups. Limiting the CSR in low-risk pregnancies is key to lowering the trend of increased CSR. ${ }^{20}$

Among developed nations, a population based 10 year analysis from 2005-2014 in US reported an overall CSR was 31.6 with group 5 accounting for the most caesarean deliveries. ${ }^{21}$ In most highincome settings, groups 5,2 and 1 are the major contributors to overall CSR unlike the studies from low-income settings. ${ }^{22,23}$ The difference between high-income settings and our study may be due to fertility trends with stronger presentation of multiparous women (group 3) in our low-resource setting with high fertility rates. Induction of labor (group 2) is more frequently practiced in highincome settings with the expected increase in CS for failed induction. ${ }^{24}$ The fact that group 5 women were one of the major contributors both in highincome and low-income settings indicates the importance of preventing primary caesarean if a meaningful reduction in overall CSR is to be achieved. The practice of vaginal birth after $\mathrm{C}$-section (VBAC) for non-recurrent indications in the previous $\mathrm{C}$-section can be applied to reduce $\mathrm{C}$-section in this group of patients. ${ }^{25}$

The strength of this study is the inclusion of all CS performed since the inception of obstetric services in the hospital for a period of five years. Since the hospital remains the only tertiary level hospital in the country catering to armed service personnel, their families and ex-servicemen and their families, it receives a large number of both complicated and uncomplicated pregnancies from the entire country. Limitation of this study remains the retrospective nature of this study and subsequently inability to 
compute relative size of each Robson groups, comparing women who underwent CS with women who gave birth vaginally in each of the groups. Hence, CSR in each of the groups could not be calculated for comparison with other published studies.

\section{CONCLUSIONS}

Application of Robson's Ten-group classification in our centre has helped to identify the main groups of subjects who had the overall maximum CSR. Nulliparous and multiparous women in term pregnancy in labor and women who have had previous caesarean section contribute to more than $70 \%$ of overall caesarean sections. Close monitoring of these groups of patients, increasing the use of instrumental delivery and practice of vaginal birth after $\mathrm{C}$-section can significantly reduce the CSR in our centre.

To cite this article: Malla RV, Hamal C, Neupane B, Khatri R. Analysis of caesarean section using Robson's 10-group classification at a tertiary level hospital in Nepal. MJSBH. 2018;17(2):4-11.

Conflict of Interest: None declared

\section{REFERENCES}

1. Ye J, Betrán AP, Guerrero Vela M, Souza JP, Zhang J. Searching for the optimal rate of medically necessary caesarean delivery. Birth. 2014;41(3):237-44.

DOI: https://doi.org/10.1111/birt.12104 PMid:24720614

2. Timor-Tritsch IE, Monteagudo A. Unforeseen consequences of the increasing rate of caesarean deliveries:early placenta accreta and caesarean scar pregnancy. A review. Am J Obstet Gynecol. 2012; 207(1):14-29.

DOI: 10.1016/j.ajog.2012.03.007 PMID:22516620

3. Gregory KD, Jackson S, Korst L, Fridman M. Caesarean versus vaginal delivery: whose risks? Whose benefits? Am J Perinatol. 2012;29(1):7-18.

DOI: 10.1055/s-0031-1285829 PMID: 21833896

4. WHO. Monitoring obstetric care: a handbook. Geneva: WHO Press, World Health Organization, 2009.

5. WHO. Appropriate technology for birth. Lancet. 1985;2:436-7.

6. Department of Health and Human Services; Centers for Disease Control and Prevention; National Center for Health Statistics. Healthy People 2000: national health promotion and disease prevention objectives: Full report, with commentary (DHHS publication no. (PHS) 91-50212). Washington: Government Printing Office; 1990:378.

7. World Health Organization Human Reproduction Programme, 10 April 2015. WHO statement on caesarean section rates. Reprod Health Matters. 2015;23:149-50.

DOI: https://doi.org/10.1016/j.rhm.2015.07.007 PMid:26278843

8. Torloni MR, Betran AP, Souza JP, Widmer M, Allen T, Gulmezoglu M, et al. Classifications for cesa $\neg$ rean section: a systematic review. PLoS ONE. 2011;6(1):e14566. 
DOI: https://doi.org/10.1371/journal.pone.0014566 PMCid:PMC3024323

9. Robson MS. Classification of caesarean sections. Fetal and Maternal Medicine Review. 2001;12(1): 23-39.

DOI: https://doi.org/10.1017/S0965539501000122

10. Betran AP, Vindevoghel N, Souza JP, Gulmezoglu AM, Torloni MR. A Systematic Review of the Robson Classification for Caesarean Section: What Works, Doesn't Work and How to Improve It. PLoS One. 2014;9(6):e97769.

DOI: https://doi.org/10.1371/journal.pone.0097769 PMid:24892928

11. Vaidya S, KC I, Shrestha P. Statistics of Paropakar Maternity and Women's Hospital 2071/2072. Smarika: 56 th Anniversary. Bagmati offset press, Kathmandu. 2016: 59-62.

12. Amatya A, Paudel R, Poudyal A, Wagle RR, Singh M, Thapa S. Examining stratified caesarean section rates using Robson classification system at Tribhuvan University Teaching Hospital. J Nepal Health Res Counc. 2013;11(25):255-8.

13. Chhetri S, Singh U. Caesarean section: its rate and indications at tertiary referral centre in Eastern Nepal. J Med Science. 2011;9(3):179-83.

DOI: https://doi.org/10.3126/hren.v9i3.5587

14. Dhakal R, Neupane N, Adhikari S. Trends of Caesarean Section: A Hospital Based Retrospective Study. Saudi J. Med. Pharm. Sci. 2018; 4(1A): 90-94.

15. Betran AP, Ye J, Moller AB, Zhang J, Gulmezoglu AM, Torloni MR. The increasing trend in caesarean section rates: global, regional and national estimates: 1990-2014. PLoS One. 2016;11:e0148343.

DOI: https://doi.org/10.1371/journal.pone.0148343

16. Tura AK, Pijpers O, de Man M, Cleveringa M, Koopmans I, Gure T, et al. Analysis of caesarean sections using Robson 10-group classification system in a university hospital in eastern Ethiopia: a crosssectional study. BMJ Open. 2018;8:e020520.

DOI: https://doi.org/10.1136/bmjopen-2017-020520

\section{PMid:29622577}

17. Makhanya V, Govender L, Moodley J. Utility of the Robson Ten Group Classification System to determine appropriateness of caesarean section at a rural regional hospital in KwaZulu-Natal, South Africa. S Afr Med J. 2015;105:292-5.

DOI: https://doi.org/10.7196/SAMJ.9405 PMid:26294873

18. Litorp H, Kidanto HL, Nystrom L, Darj E, Essén B. Increasing caesarean section rates among low-risk groups: a panel study classifying delivery according to Robson at a university hospital in Tanzania. BMC Pregnancy Childbirth. 2013;13:107.

DOI: https://doi.org/10.1186/1471-2393-13-107

19. Yadav RG, Maitra N. Examining Caesarean Delivery Rates Using the Robson's Ten-group Classification. J Obstet Gynaecol India. 2016 Oct;66(1):1-6

DOI: https://doi.org/10.1007/s13224-015-0738-1

PMid:27651569 
20. Delbaere I, Cammu H, Martens E, Tency I, Martens G, Temmerman M. Limiting the caesarean section rate in low risk pregnancies is key to lowering the trend of increased abdominal deliveries: an observational study. BMC pregnancy and childbirth. 2012 Dec;12(1):3.

DOI: https://doi.org/10.1186/1471-2393-12-3 PMid:22230339

21. Hehir MP, Ananth CV, Siddiq Z, Flood K, Friedman AM, D'Alton ME. Caesarean delivery in the United States 2005 through 2014: a population-based analysis using the Robson 10-group classification system. Am J Obstet Gynecol. 2018 Apr.

DOI: https://doi.org/10.1016/j.ajog.2018.04.012

22. Kelly S, Sprague A, Fell DB, Murphy P, Aelicks N, Guo Y, et al. Examining caesarean section rates in Canada using the Robson classification system. Journal of Obstetrics and Gynaecology Canada. 2013 Mar;35(3):206-14.

DOI: https://doi.org/10.1016/S1701-2163(15)30992-0

23. Stavrou EP, Ford JB, Shand AW, Morris JM, Roberts CL. Epidemiology and trends for Caesarean section births in New South Wales, Australia: a population-based study. BMC pregnancy and childbirth. 2011 Dec;11(1):8.

DOI: https://doi.org/10.1186/1471-2393-11-8

24. Rayburn WF, Zhang J. Rising rates of labor induction: present concerns and future strategies. Obstet Gynecol. 2002;100:164-7.

DOI: https://doi.org/10.1097/00006250-200207000-00024

25. Gardner K, Henry A, Thou S, Davis G, Miller T. Improving VBAC rates: the combined impact of two management strategies. Aust N Z J Obstet Gynaecol. 2014 Aug;54(4):327-32.

DOI: 10.1111/ajo.12229 